Bangladesh J. Sci. Res. 28(2): 137-149, 2015 (December)

\title{
YIELD AND WATER PRODUCTIVITY OF MUSTARD UNDER SPRINKLER AND BASIN IRRIGATION SYSTEMS
}

\author{
A.J. Mila*, A.R. Akanda, S.K. Biswas, P.K. Sarkar ${ }^{1}$ and S. Pervin ${ }^{2}$ \\ Irrigation and Water Management Division, BARI, Gazipur-1701, Bangladesh
}

\begin{abstract}
Field experiment was conducted during two consecutive years (2011-12 and 2012-13) to investigate the yield and water productivity (WP) of mustard (BARI Sarisha-14 variety) using sprinkler irrigation. There were six irrigation treatments (sprinkler irrigation at vegetative $\left(T_{1}\right)$, pre-flowering $\left(\mathrm{T}_{2}\right)$ and pod formation $\left(\mathrm{T}_{3}\right)$ stage, sprinkler irrigation at vegetative and pod formation stage $\left(\mathrm{T}_{4}\right)$, sprinkler irrigation at pre-flowering and pod formation stage $\left(\mathrm{T}_{5}\right)$; and basin irrigation at vegetative, pre-flowering, and pod formation stage $\left(\mathrm{T}_{6}\right)$ (farmer's practice). Results indicate that yield and yield components responded positively against different soil moisture regime. The significant highest yield (1.41 and $1.37 \mathrm{t} / \mathrm{ha}$ ) was obtained by applying basin irrigation at three growth stages, with no statistical difference in yield (1.38 and $1.34 \mathrm{t} / \mathrm{ha})$ with the application of sprinkler irrigation at vegetative and pod formation stages. Vegetative stage was the most critical stage to sprinkler irrigation and pod formation is the next most sensitive stage for mustard cultivation. Sprinkler irrigation can save more than 65 and $35 \%$ of water with the yield reduction of 12.96 and $2.16 \%$, respectively, in treatment $\mathrm{T}_{1}$ and $\mathrm{T}_{4}$ compared to treatment $\mathrm{T}_{6}$. These treatments $\left(\mathrm{T}_{1}\right.$ and $\left.\mathrm{T}_{4}\right)$ also gave higher water productivity, irrigation water productivity, and net revenue than treatment $\mathrm{T}_{6}$. The results will be helpful for policy planning regarding efficient irrigation and water management under water scarce situation.
\end{abstract}

Key words: Deficit irrigation, irrigation water productivity, soil moisture content, relative water saving

\section{Introduction}

Mustard is an important oil seed crop grown in Bangladesh. The present cultivation area and production of mustard is $0.28 \mathrm{mha}$ and $0.26 \mathrm{mt}$, respectively (BBS 2013). Among the varieties, BARI Sarisha-14 is one of the popular short-durated varieties (85- 90 days), can easily fit in any cropping pattern across the country. After harvesting this crop farmers can easily cultivate boro rice. It is generally grown by utilizing post monsoon soil moisture. But in most places, the crop cannot produce optimum yield with residual soil moisture only if the rainfall is inadequate (Akanda et al. 1996). Therefore, farmers can cultivate this variety by irrigating three times with the use of basin irrigation with hose pipe. Due to this, they waste more water by conveyance loss and field loss (about 40\%). Water is becoming a scarce input particularly in semi-arid regions

*Author for correspondence: <afrinbau@gmail.com>. ${ }^{1}$ IWM Department, Sylhet Agricultural University, Sylhet, Bangladesh, ${ }^{2}$ Postharvest Technology Division, BARI, Gazipur, Bangladesh. 
owing to climate change, persistent drought, increased water demand on irrigated surface, excessive growth of population and socio-economic development (Kharrou et al. 2011, Buttar et al. 2006). Besides, water unavailability throughout the growing season is a threat for agricultural productivity and food security ( $\mathrm{Li}$ et al. 2010), creates extreme pressure on ground water resources. To cope with this, efficient utilization of available water resources is necessary to minimize this loss of irrigation. In this study sprinkler irrigation method is chosen for efficient water management and basin irrigation method (efficiency is about $40-60 \%$ ) is used as a traditional method. Also, it is a water saving and preferred method for water limiting areas (Uddin et al. 2013) and its use is increasing steadily (Yazar et al. 2002).

Sprinkler irrigation is one of the useful technologies which can enhance crop production (Michael 2014b) and water productivity (WP) (Liu and Kang 2006). Many researchers did experiment on sprinkler irrigation with different crops (Liu and Kang 2006, Martinez-Cob et al. 2008). Akanda et al. (1996) found that the highest seed yield of mustard (1217 kg/ha) was produced with the application of three irrigations, each at vegetative, flowering and pod formation stages at Gazipur and Ishordi by using basin irrigation. However, Khan and Agarwal (1985) obtained economically higher yield of mustard by applying single irrigation amounting to 93.00 $\mathrm{mm}$ of water. Mandal et al. (2006) found that single irrigation after sowing can be reduced by the application of 100 per cent of NPK with organic manure without hampering the yield of Indian mustard under deficit irrigation in central India.

Water productivity is an important matter for anticipating future water demands (Amarasinghe et al. 2004). Sprinkler irrigation plays an important role with the increase of water productivity. It is necessary to increase water productivity by decreasing the applied water volume without affecting crop yield especially in water scarce regions (Bebhoudian and Singh 2002). All the studies were done previously with the objective of either minimizing ET loss or increasing production with the application of increased irrigation water. Therefore, this study has been undertaken to investigate the yield response of mustard under different soil moisture regimes, to schedule irrigation application under consideration of water availability, to determine the water sensitive stages and water productivity and to compare the economic feasibility of sprinkler and basin irrigation.

\section{Materials and Methods}

The experiment was conducted at the research field of Irrigation and Water Management Division, Bangladesh Agricultural Research Institute, Gazipur during the winter season of 2012 to 2013 with the variety of BARI Sarisha-14. The average annual rainfall was about $1897.63 \mathrm{~mm}$ (BBS 2013).

The soil characteristic of experimental field was sandy clay in texture, with a bulk density of $1.49-1.50 \mathrm{~g} / \mathrm{cm}^{3}$ and volumetric water content at permanent wilting point and field capacity (FC) was 14.1 and $29.0 \%$, respectively. The average $\mathrm{pH}$ of the soil was 6.45 (Table 1). It was a warm dry climate with the maximum temperature of 32 and $32.2^{\circ} \mathrm{C}$, minimum temperature of 18 and 


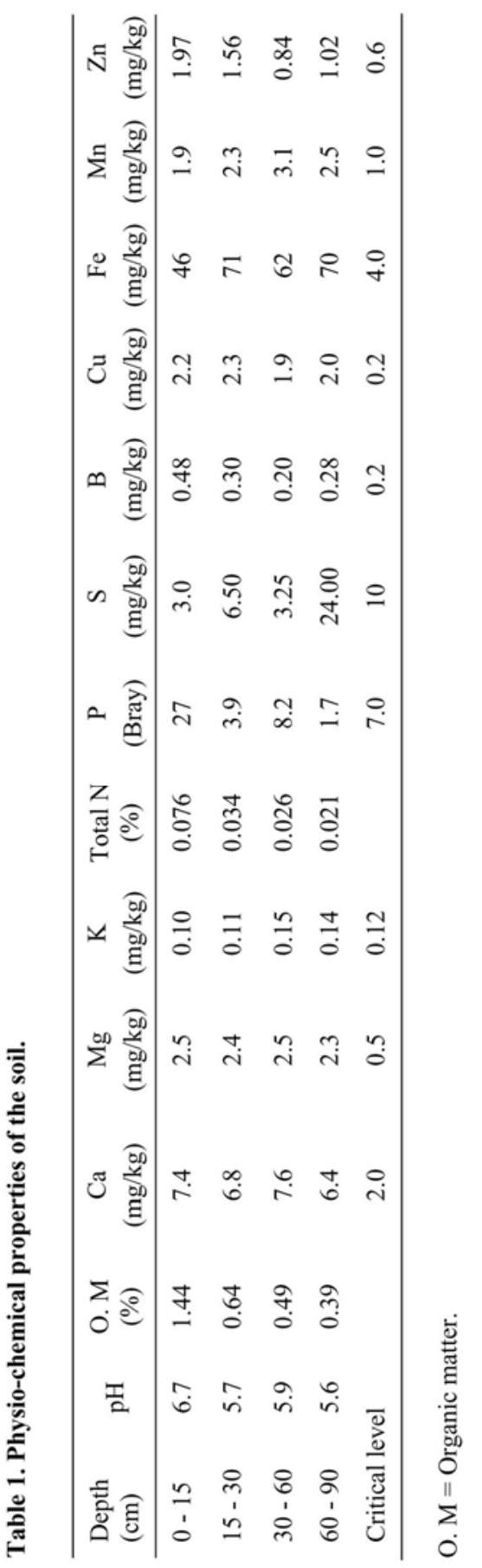


$21.4^{0} \mathrm{C}$, relative humidity of $93 \%$, evaporation of 5.3 and $4.9 \mathrm{~mm}$, sunshine of 9.7 and 9.49 hour, and wind speed of 71 and $107 \mathrm{~km} / \mathrm{hr}$ during 2012 and 2013, respectively (Fig. 1). Soil physiochemical properties were determined by following Graham et al. (2013), Bremner and Mulvaney (1982), Nelson and Sommers (1996), Olson and Sommers (1982), Lindsay and Norvell (1978), Fox (1964).
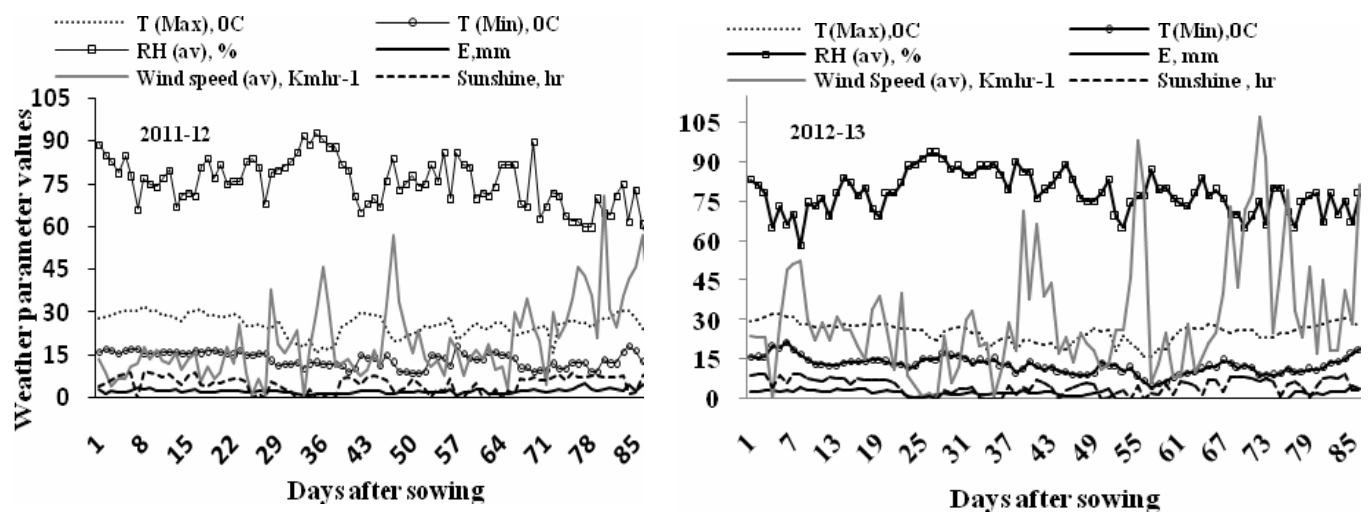

Fig.1. Weather conditions of the study area over two years during the crop period.

The variety, BARI Sarisha-14 was sown in line on 17th and 15th November 2011 and 2012 at a rate of $6.5 \mathrm{~kg} / \mathrm{ha}$. The unit plot size and spacing were $3.9 \mathrm{~m} \times 4.95 \mathrm{~m}$ and $30 \mathrm{~cm} \times 15 \mathrm{~cm}$, respectively. The experimental design was randomized complete block with three replications and six irrigation treatments viz. $\mathrm{T}_{1}, \mathrm{~T}_{2}$, and $\mathrm{T}_{3}=$ Sprinkler irrigation at vegetative $(\mathrm{V})$, pre-flowering $(\mathrm{PF})$, and pod formation $(\mathrm{P})$ stage, respectively (20, 35, and 55 days after sowing), $\mathrm{T}_{4}=$ Sprinkler irrigation at $\mathrm{V}$ and $\mathrm{P}$ stages (20 and 55 days after sowing), $\mathrm{T}_{5}=$ Sprinkler irrigation at $\mathrm{PF}$ and $\mathrm{P}$ stages ( 35 and 55 days after sowing), and $\mathrm{T}_{6}=$ Basin irrigation at $\mathrm{V}, \mathrm{PF}$ and $\mathrm{P}$ stage $(20,35$ and 55 days after sowing). Fertilizers were applied at the rate of $\mathrm{N}_{104} \mathrm{~kg} / \mathrm{ha}$ as urea, $\mathrm{P}_{32} \mathrm{~kg} / \mathrm{ha}$ as TSP, $\mathrm{K}_{39}$ $\mathrm{kg} / \mathrm{ha}$ as MP, $\mathrm{S}_{24} \mathrm{~kg} / \mathrm{ha}$ as gupsum, $\mathrm{Zn}_{1.2} \mathrm{~kg} / \mathrm{ha}$ as zinc sulphate and $\mathrm{B}_{1.0} \mathrm{~kg} / \mathrm{ha}$ as boric acid, respectively (FRG 2012). Two-third of $\mathrm{N}$ and total amount of other fertilizers were applied at the time of final land preparation and remaining $\mathrm{N}$ was applied as top dress after first irrigation. A common irrigation of $10 \mathrm{~mm}$ was applied after sowing for ensuring proper emergence. Intercultural operations, such as weeding, thinning and pesticide (Diazinon 60 EC) application were done whenever necessary.

After 20 to 25 days of pod formation, it reached its physiological maturity and harvesting was done on 12th and 8th February 2012 and 2013, respectively.

At the time of harvesting, middle nine (09) rows out of 13 were selected randomly to collect 10 plants from each replication to avoid border effect. The data on plant height, number of branch per plant, and pod number per plant were collected after harvest. After threshing and cleaning, data on grain yields ( $12 \%$ moisture content) and yield contributing characters were recorded. 
The measured data were analyzed statistically by using $\mathrm{R}$ software (Version 3.1.1). Mean separation was done by least significant difference (LSD) test at $5 \%$ level of probability.

Crop evapotranspiration (ET) was calculated by the following water balance equation (Karam et al. 2014).

$\mathrm{ET}=\mathrm{I}+\mathrm{P} \pm \Delta \mathrm{S}-\mathrm{R}-\mathrm{D}$

where, ET is evapotranspiration $(\mathrm{mm})$, I is the depth of irrigation water $(\mathrm{mm}), \mathrm{P}$ is the precipitation $(\mathrm{mm}), \Delta \mathrm{S}$ is the change in soil water storage $(\mathrm{mm}), \mathrm{R}$ is the runoff, and $\mathrm{D}$ is the drainage below the root zone. In the equation, time-volume technique (Grimes et al. 1987) was used to irrigate (I) the crop. Soil water content was monitored in each plot by using the gravimetric method. Then, irrigation water amount of each plot was converted to time (min) and applied. The source of water was fresh underground and carried out by using plastic hose pipe of $30 \mathrm{~mm}$ in diameter. Irrigation water was applied to bring the soil moisture up to field capacity. Soil moisture was measured from different layers at every 10 days intervals. Precipitation was observed at the agro-meteorological station which was very close to the experimental field, $\Delta \mathrm{S}$ obtained from gravimetric moisture observations in the soil profile to a depth of $60 \mathrm{~cm}$. There was no surface runoff and drainage as measured quantity of water was applied to fill the gap between FC and soil moisture at the time of irrigation. The following formula was used to irrigate the crop (Michael 2014a),

$$
\mathrm{I}=\frac{F C-M C_{i}}{100} \times A_{s} \times D
$$

where, $\mathrm{I}=$ Depth of water applied, $\mathrm{cm}, \mathrm{FC}=$ Field capacity moisture content, $\%$ vol. $\mathrm{Mc}_{\mathrm{i}}=$ Moisture content of the soil at the time of irrigation, \% vol. $\mathrm{A}_{\mathrm{s}}=$ Apparent specific gravity of the soil $\left(\mathrm{g} / \mathrm{cc}^{3}\right) . \quad \mathrm{D}=$ Depth of root zone, $\mathrm{cm}$.

The establishment of sprinkler irrigation method needs some initial investment cost (fixed cost) which include lateral pipe, sprinkler head and tripod stand. Land use cost was also considered as a fixed cost in a seasonal basis. For basin irrigation, lateral pipe and land use cost was considered as an initial investment cost.

\section{Results and Discussion}

The mean data on yield and yield components of BARI Sarisha-14 are presented in Table 2. All parameters were analyzed statistically and significant variation was observed. It is seen from the table that yield and yield contributing parameters responded positively with the application of water and decreased with the reduced application of water. This was due to the effect of various soil moisture contents and rainfall distribution during the crop season (Fig. 2). The significantly highest yield and yield attributes were found in treatment $\mathrm{T}_{6}$ 


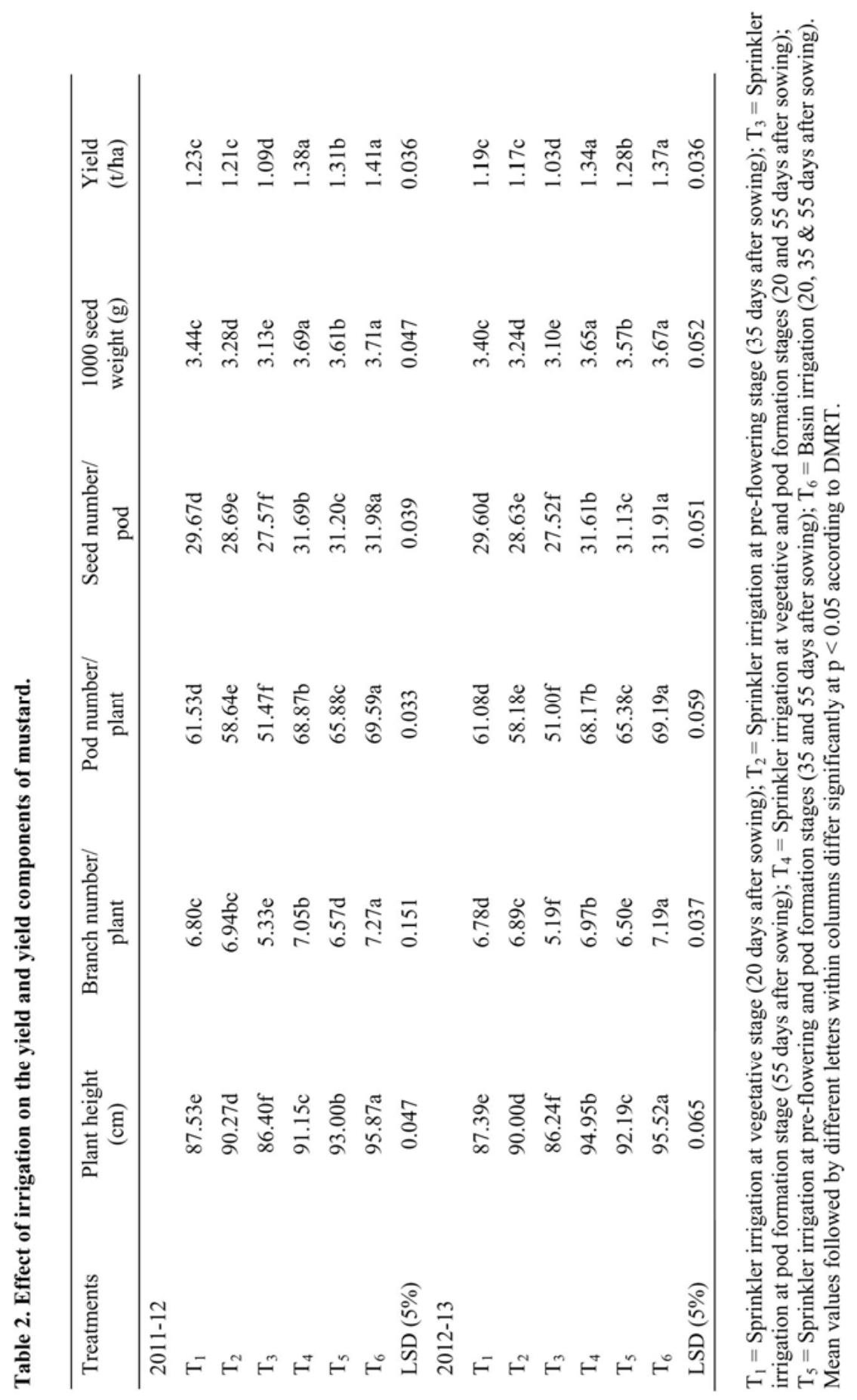


(basin irrigation at vegetative, pre-flowering and pod formation stage) and lowest in treatment $T_{3}$ (sprinkler irrigation at pod formation stage). There was no statistical difference between treatment $\mathrm{T}_{6}$ and $\mathrm{T}_{4}$ in terms of yield. This result was in agreement with Akanda et al. (1996), AICRP-RM (1999) and Mila et al. (2013). They found that three irrigations were appropriate to get the potential yield of mustard. Besides, in 1000-seed weight, there was no statistical difference between treatment $T_{6}$ and $T_{4}$ though irrigation frequency was not the same. The significant lowest yield in treatment $\mathrm{T}_{3}$ was due to the effect of a large gap (about 45 days) from crop establishment to pod formation stage was exerted and after that irrigation water was applied. This water stress is responsible for decreased cell activities to a large extent, that's why all the yield components were the lowest.

The treatments $T_{4}$ and $T_{5}$ received equal number of irrigation in different growth stages but yield reduction was $5 \%$ higher in treatment $T_{5}$ than treatment $T_{4}$. In case of treatment $T_{5}$, irrigation was omitted at the vegetative stage, consequently yield reduced to some extent. Also, in case of treatments $T_{1}, T_{2}$, and $T_{3}$, yield reduction was found highest in $T_{3}$ whereas lowest in treatment $T_{1}$. This yield reduction was due to the effect of omition of irrigation at the vegetative stage. Also, in this study sprinkler irrigation at vegetative and pod formation stages gave comparatively better yield than that of pre-flowering and pod formation stages. Therefore, it can be said that vegetative stage was the most critical stage and pod formation was the next most critical stage to sprinkler irrigation. AICRP-RM (1999) found similar result. However, Panda et al. (2004) found that irrigation at flowering and pod formation stage gave the average increase in seed yield.

Productivity of irrigation water (IWP) and water productivity (WP) under different irrigation treatments are presented in Table 3. The amount of irrigation water applied was increased with the increase of irrigation frequency. Similarly, crop water use was increased with the irrigation frequency. Sezen and Yazar (2006) found that water use increased with the increase of irrigation levels. The highest amount of water use or ET was found in treatment $\mathrm{T}_{6}$ and the lowest was found in treatment $T_{1}$. Akanda et al. (1996) observed that the average seasonal water use of mustard was 252 and $163 \mathrm{~mm}$ at Joydebpur and Jessore, respectively though they used traditional method. The highest IWP was obtained in treatment $T_{1}$ and decreased according to increasing water application. This was due to the effect of sprinkler irrigation which can create a favorable microclimate for crop growth and yield (Liu and Kang 2006). Prihar et al. (1981) found that single irrigation after 21 days after sowing gave maximum seed yield and water productivity, with $40 \%$ yield increased in 1973-74 and 30\% in 1976-77 compared with rainfed irrigation (no irrigation). Actually, this is the concept of deficit irrigation (DI) and to maximize water productivity by applying less amount of water that the crops actual need and significant yield reduction. In this study, the highest water saving was observed in treatment $T_{1}$ (sprinkler irrigation at vegetative stage), with yield reduction of $13 \%$ compared to the most water used treatment. Treatment $\mathrm{T}_{4}$ saved about $35 \%$ of water with very little amount of yield reduction compared to $\mathrm{T}_{6}$. Michael (2014b) mentioned that sprinkler irrigation can save $25-50 \%$ of water, depending on the type and design of the system than surface irrigation. 
Rainfall and soil moisture content of experimental field during different days over the growing period is presented in Fig. 2. Before sowing soil moisture was same (23.45 and 21.75\%) for all the treatments but varied after harvest.
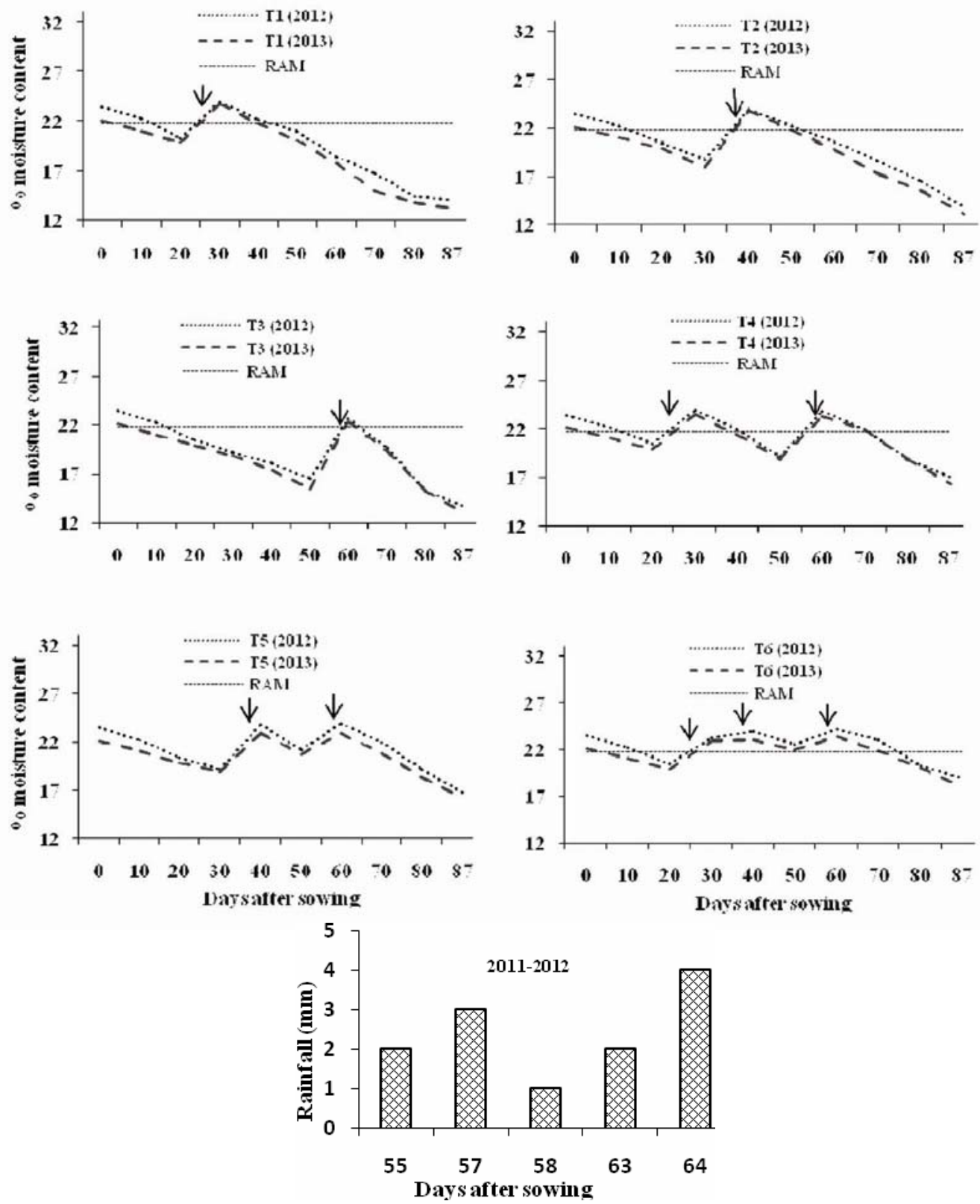

Fig. 2. Rainfall and variation of soil moisture content under different irrigation treatments during the crop season. 


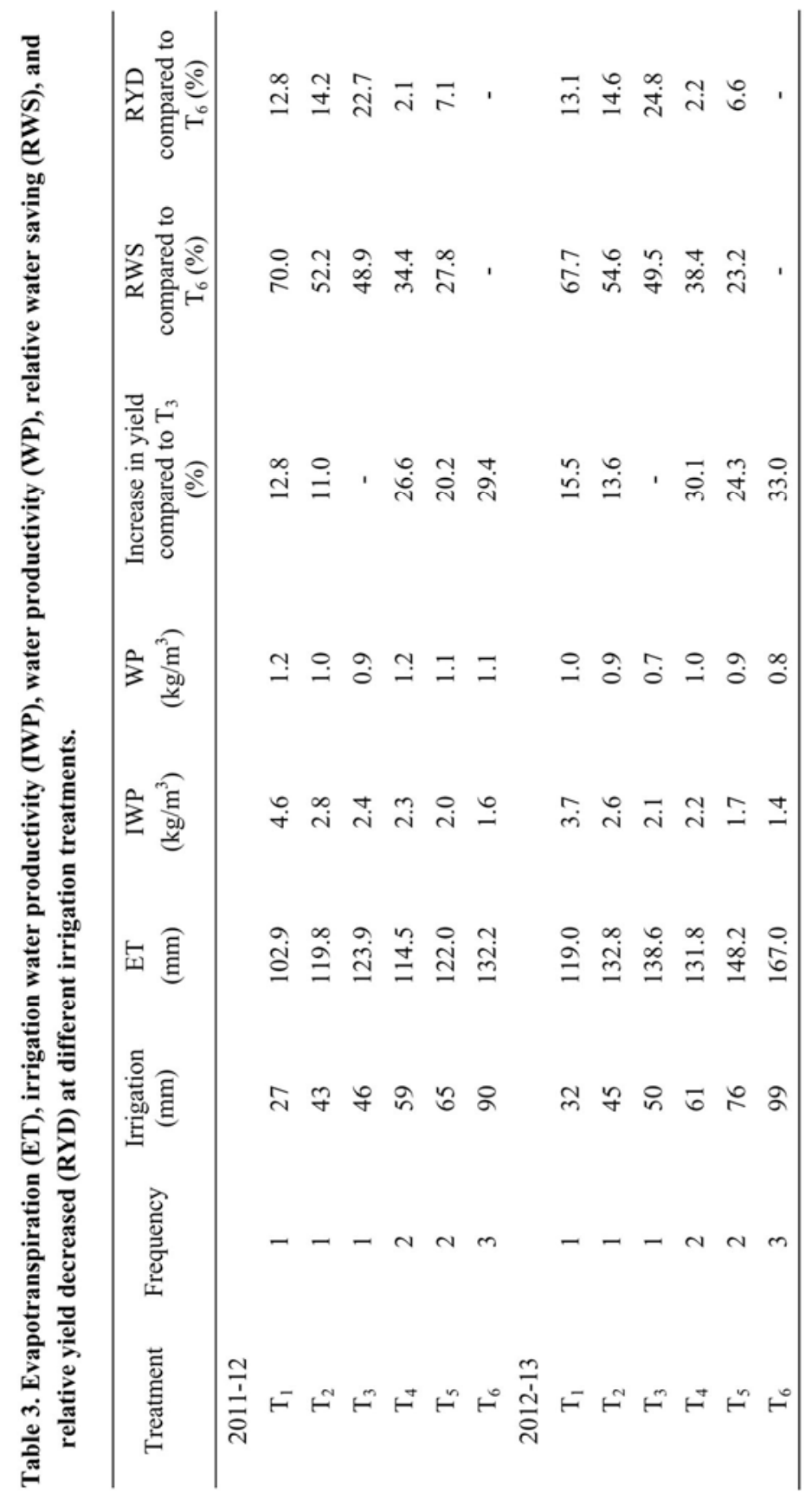


Irrigation water was applied one time in treatments $T_{1}, T_{2}$ and $T_{3}$, while two times in treatments $T_{4}$ and $T_{5}$ and three times in treatment $T_{6}$ which is shown in Fig. 2 by inserting downward arrow. Very little amount of rainfall $(12 \mathrm{~mm})$ was found during the crop season in the year 2012. Finally, it was found that after harvests soil moisture in treatments $T_{1}, T_{2}$ and $T_{3}$ were below the wilting point (14.1\%) and moisture content was under the range of available moisture content during the crop period. Besides, during the crop season treatment $\mathrm{T}_{4}, \mathrm{~T}_{5}$ and $\mathrm{T}_{6}$ was within the readily available moisture content (RAM). Among them soil moisture in treatment $\mathrm{T}_{6}$ fluctuated, very close to RAM that's why gave the highest yield (Table 3).

Table 4 shows comparative establishment cost between sprinkler and basin irrigation method. In this analysis, cost effectiveness was evaluated in treatment $\mathrm{T}_{1}$, and $\mathrm{T}_{4}$ which performed better among other sprinkler irrigation treatments in terms of water productivity (WP), irrigation water productivity (IWP), relative water saving and relative yield decreased. The highest fixed cost per season was found in sprinkler irrigation method than basin irrigation method. Farmers will bear this additional cost until the life of the sprinkler set.

Table 4. Establishment cost of basin and sprinkler irrigation in mustard cultivation (average of years).

\begin{tabular}{|c|c|c|c|c|c|c|c|}
\hline \multirow{2}{*}{$\begin{array}{l}\text { S1. } \\
\text { No. }\end{array}$} & \multirow{2}{*}{ Item } & \multirow{2}{*}{ Quantity } & \multirow{2}{*}{$\begin{array}{l}\text { Rate } \\
\text { (Tk) }\end{array}$} & \multicolumn{2}{|c|}{ Initial investment (Tk) } & \multicolumn{2}{|c|}{ Cost/season } \\
\hline & & & & Basin & Sprinkler & Basin & Sprinkler \\
\hline 1 & $25.4 \mathrm{~mm}$ dia. hose pipe & $48 \mathrm{~m}$ & 174 & 8352 & 8352 & 138.68 & 138.68 \\
\hline 2 & Tripod sprinkler & 30 & 1200 & - & 36000 & - & 480 \\
\hline 3 & Land use cost & 24189 & & & & 24189 & 24189 \\
\hline 4 & Total Fixed cost & - & - & - & & 24328 & 24808 \\
\hline
\end{tabular}

Life of pipe/lateral $=20$ years, life of sprinkler head $=25$ years, and life of tripod stand $=25$ years.

Table 5 presents financial profitability of basin and sprinkler irrigation method. The highest net return and benefit cost ratio was found in treatment $\mathrm{T}_{4}$ (sprinkler irrigation at vegetative and pod formation stage) followed by $\mathrm{T}_{1}$ (sprinkler irrigation at vegetative stage). This result was in agreement with AICRP-RM (1999). They found that maximum benefit was found by applying two irrigations each at vegetative and pod formation stage in cultivating Indian mustard. Also, single irrigation at the critical stage can give highest IWP and net return. By contrast, the lowest net return and benefit cost ratio was found in treatment $\mathrm{T}_{6}$ (basin irrigation at vegetative, pre-flowering and pod formation stage) because labour needed was about double than sprinkler irrigation method. Finally, benefit cost ratio (BCR) was found highest in treatment $T_{4}$ followed by $T_{1}$. Therefore, in consideration of net return, and BCR it can be reported that sprinkler irrigation is a suitable method for cultivating mustard under water scarce regions. 
Table 5. Profitability of basin and sprinkler irrigation in mustard cultivation (average of years).

\begin{tabular}{lccc}
\hline \multirow{2}{*}{\multicolumn{1}{c}{ Item }} & \multicolumn{2}{c}{ Sprinkler method } & Basin method \\
\cline { 2 - 4 } & $\mathrm{T}_{1}$ & $\mathrm{~T}_{4}$ & $\mathrm{~T}_{6}$ \\
\hline A. Variable cost (Thousand) & 29.1 & 35.1 & 48.5 \\
Seed (Tk) & 0.5 & 0.5 & 0.5 \\
Land preparation (Tk) & 5.1 & 5.1 & 5.1 \\
Fertilizer (Tk) & 13.2 & 13.2 & 13.2 \\
Pesticide (Tk) & 1.5 & 1.5 & 1.5 \\
Irrigation (Tk) & 1.9 & 5.9 & 9.0 \\
Labour (Tk) & 7.0 & 9.0 & 18.0 \\
B. Fixed cost (Thousand) & 24.8 & 24.8 & 24.3 \\
C. Total cost (A+B) (Thousand) & 53.9 & 59.9 & 72.8 \\
D. Gross return (Thousand) & 86.1 & 96.6 & 98.7 \\
Yield (t/ha) & 1.23 & 1.38 & 1.41 \\
Price (Tk./ton) & 70.0 & 70.0 & 70.0 \\
E. Net return (D-C) (Thousand) & 32.2 & 36.7 & 25.9 \\
F. BCR & 1.60 & 1.61 & 1.36 \\
\hline
\end{tabular}

Based on the performance of sprinkler irrigation treatment, $T_{1}$ and $T_{4}$

\section{Conclusion}

Sprinkler irrigation is an efficient irrigation method than basin irrigation method for semi-arid areas. It increases water productivity by creating water stress in different growth stages as fresh water is scarce. This method can save more water than conventional method but initial investment cost is a prime drawback for adopting this technology. This technique can also save time and reduce labor cost than that of surface method. By utilizing this technique excessive groundwater withdrawal can be minimized. Therefore, sustaining agricultural production can be achieved (Ali et al. 2011, 2012). More than 65 and 35\% of water can be saved by using sprinkler irrigation at vegetative, and vegetative and pod formation stage, respectively. This technique can also save conveyance and field loss to a great extent.

For water scarce situation, sprinkler irrigation at vegetative, and vegetative and pod formation stage can gave highest net return and irrigation water productivity than conventional method (basin irrigation). This information can help policy planning regarding efficient irrigation and water management under prevailing water scarce situation. Farmers can adopt this technology easily if government can take necessary step to reduce its initial cost. Vegetative stage was the most critical stage and pod formation stage was the next most sensitive stage to sprinkler irrigation. 
Therefore, from the evaluation of yield, irrigation amount applied, irrigation water productivity, water productivity, relative water savings, relative yield reduction, net return and benefit cost ratio, the sprinkler irrigation can be adopted for judicious utilization of water resources. As initial cost is high community basis sprinkler irrigation system may be introduced for small and marginal farmers.

\section{References}

AICRP-RM, 1999. Annual Progress Report of All India Coordinated Research Project on Rapeseed-Mustard, pp. A1-44.

Akanda, M. A. R., M. S. Islam, B. R. Khan and M. R. I. Mondal. 1996. Response of mustard (Brassica napus L.) to irrigation at different stages of growth. Thai J. Agric. Sci. 29: 191-199.

Ali, M. H., I. Abustan, M. A. Rahman and A. A. M. Haque. 2011.Sustainability of groundwater resources in the north-eastern region of Bangladesh. Water Resource Manage 26: 623-641.

Ali, M. H., A. A. Sarkar and M. A. Rahman. 2012. Analysis on groundwater-table declination and quest for sustainable water use in the north-western region (Barind area) of Bangladesh. J. Agril. Sci. Applications 1:26-32.

Amarasinghe, U., R. Bharat, N. A. Sharma, S. Christopher, V. Smakhtin, C. de Fraiture, A. K. Sinha and A. K. Shukla. 2004. Spatial variation in water supply and demand across river basins of India. IWMI Research Report 83, Colombo, Sri Lanka.

BBS (Bangladesh Bureau of Statistics). 2013. Statistical Yearbook of Bangladesh (33 $3^{\text {rd }}$ edition), Ministry of planning, Government of the People's Republic of Bangladesh, December, 2014.

Behboudian, M. H. and Z. Singh. 2002. Water relations and scheduling in grapevine. Hortic. Rev. 27: $189-225$.

Bremner, J. M. and C. S. Mulvaney. 1982. Nitrogen - total. In:Methods of soil analysis. Part 2. Chemical and microbiological properties. pp. 595-624.

Buttar, G. S., H. S. Thind and M. S. Aujla. 2006. Methods of planting and irrigation at various levels of nitrogen affect the seed yield and water use efficiency in transplanted oilseed rape (Brassica napus L.). Agric. Water Manage. 85: 253-260.

Fox, J. E. 1964. Indoleacetic acid-kinetin antagonism in certain tissue culture systems. Plant and Cell Physiology 5: 251-254.

FRG, 2012.Fertilizer Recommendation Guide, Bangladesh Agricultural Research Council, Farmgate, Dhaka1215. p. $106<$ www.barc.gov.bd>

Graham, D.J., B.Jaselskis and C.E. Moore. 2013. Development of the Glass Electrode and the pH Response. Journal of Chemical Education 90: 345-351.

Grimes, D. W., H. Yamada and S. W. Hughes. 1987. Climate-normalized cotton leaf water potentials for irrigation scheduling. Agric. Water Manage. 12: 293-304.

Karam, F., N. Amacha, S. Fahed, T. EL Asmar, and A. Dominguez. 2014. Response of potato to full and deficit irrigation under semiaridclimate: Agronomic and economic implications. Agric. Water Manage. 142: $144-151$.

Khan, G. M. and B. K. Agarwal. 1985. Water use, water use efficiency and soil moisture extraction pattern of mustard in relation to water stress and sowing methods. Indian J. Agron. 30: 235-243. 
Yield and water productivity of mustard under sprinkler irrigation

Kharrou, M. H., S. Er-Raki, A. Chehbouni, B. Duchemin, V. Simonneaux, M. LePage, L. Ouzine and L. Jarlan. 2011. Water use efficiency and yield of winter wheat under different irrigation regimes in a semiarid region. Agric. Sci. 2: 273-282.

Li, X., S. R. Waddington, J. Dixon, A. K. Joshi and M. C. de Vincente. 2010. The relative importance of drought and other water-related constraints for major food crops in south Asian farming systems. Food Secur 3:19-33.

Lindsay, W. L. and W. A. Norvell. 1978. Development of a DTPA soil test for zinc, iron, manganese, and copper. Soil Science Society of America Journal 42: 421-428.

Liu, H. and Y. Kang. 2006. Effect of sprinkler irrigation on microclimate in the winter wheat field in the north China Plain. Agric. Water Manage. 84: 3-19.

Mandal, K. G., K. M. Hati, A. K. Misra and K. K. Bandyopadhyay. 2006. Assessment of irrigation and nutrient effects on growth, yield and water use efficiency of Indian mustard (Brassica juncea) in central India. Agric. Water Manage. 85: 279-286.

Martinez-Cob, A., E. Playan, N. Zapata, J. Cavero, E.T. Medina and M. Puig. 2008. Contribution of evapotranspiration reduction during sprinkler irrigation to application efficiency. Journal of Irrigation and Drainage Engineering 134: 745-756.

Michael, A. M. 2014a. Water requirement of crops and irrigation management. In: Irrigation Theory and Practice, $2^{\text {nd }}$ Edition, Vikas Publishing House, India. pp. 478-553.

Michael, A. M. 2014b. Sprinkler irrigation. In: Irrigation Theory and Practice, $2^{\text {nd }}$ Edition, Vikas Publishing House, India. pp. 578-609.

Mila, A.J., A. A. Sarkar, N.N. Karim and N. Islam. 2013. Yield response of a mustard mutant variety to different times of irrigation. Bangladesh J. Sci. Res. 26: 89-93.

Nelson, D. W. and L. E. Sommers. 1996. Total carbon, organic carbon, and organic matter. Methods of soil analysis. Part 3: 961-1010.

Olson, S. R. and L. E. Sommers. 1982. Phosphorus. P. 403-430. In A.L. Page et al. (eds) Methods of soil analysis. Part 2. $2^{\text {nd }}$ ed. Agron. Monogr. 9. ASA and SSSA, Madison, WI.

Panda, B. B., S. K. Bandyopadhyay and Y. S. Shivay. 2004. Effect of irrigation level, sowing dates and varieties on yield attributes, yield, consumptive water use and water-use efficiency of Indian mustard. Ind. J. Agril. Sci.74: 339-342.

Prihar, S. S., K. S. Sandhu, K.L. Khera and B.S. Sandhu. 1981. Effects of Irrigation schedules on yield of mustard (Brassica Juncea L.).Expt. Agril. 17: 105-111.

Sezen, S. M. and A. Yazar. 2006. Wheat yield response to line-source sprinkler irrigation in the arid Southeast Anatolia region of Turkey. Agric. Water Manage. 81: 59-76.

Uddin, J., R.J. Smith, N.H. Hancock and J.P. Foley. 2013. Evaporation and sapflow dynamics during sprinkler irrigation of cotton. Agric. Water Manage.125: 35-45.

Yazar, A., S. M. Sezen, and S. Sesveren. 2002. LEPA and trickle irrigation of cotton in the Southeast Anotolia Project area in Turkey. Agric. Water Manage. 54: 189-203.

(Manuscript received November 02, 2015; revised on December 12, 2015) 